\title{
Evaluasi Pengembangan Usaha Ekonomi Produktif di Desa Sebangau Mulya Sekitar Kawasan Taman Nasional Sebangau
}

\author{
Tito Surogo ${ }^{1, *}$, Revi Sunaryati ${ }^{2,3}$, Masliani $^{2,3}$ \\ ${ }^{1}$ Balai Taman Nasional Sebangau \\ ${ }^{2}$ Program Studi Magister Pengelolaan Sumberdaya Alam dan Lingkungan Program Pascasarjana Universitas Palangka Raya \\ ${ }^{3}$ Fakultas Pertanian Universitas Palangka Raya \\ * Korespondensi: Tito Surogo (Email: titosurogo@gmail.com)
}

\begin{abstract}
Taman Nasional Sebagau (TNS) or Sebangau National Park has been now striving to provide optimal benefits for the community surrounding its area through productive economic business development program, as it did in one buffer village, namely Sebangau Mulya. This program aims to improve community welfare, and as a form of community involvement in preserving the TNS area. However, the success of the program remains questionable. This study aims, first, to examine the development of productive economic business programs in Sebangau Mulya Village. Second, to analyze the effect of such program on the welfare of villagers. The research sample was 40 villagers who received direct assistance from the program. This figure account for $10 \%$ of the villagers. Descriptive analysis and multiple linear regression were used to study the relationship of 7 independent variables, namely facilitators (X1), institutions (X2), human resources capacity (X3), skills and knowledge of human resources (X4), type of productive economic assistance (X5), counseling and training (X6) and supervision (X7) with 1 dependent variable, i.e. community welfare. The results show that the program has been providing positive benefits, marked by the increase of cattle and goats number, compared to those provided by TNS management five years before. In addition, the program has been successfully tying villagers and TNS management in maintaining and managing the area according to the planned agenda. The factors that partially influence the beneficiaries welfare is skills and knowledge (X4), which is amounting to $26.80 \%$. Since the community in carrying out productive economic businesses is in accordance with their skills and knowledge so that they are able to develop ideal businesses with the environmental conditions of Sebangau Mulya Village. Other six factors have no significant effect on villagers' welfare.
\end{abstract}

\section{Keywords}

Evaluation, productive economy, national park, Sebangau Mulya village

\section{PENDAHULUAN}

Kawasan Sebangau ditunjuk menjadi kawasan konservasi berupa Taman Nasional Sebangau berdasarkan Surat Keputusan Menteri Kehutanan No. SK423/Menhut/II/2004 tanggal 19 Oktober 2004 dengan luas \pm 568.700 ha. Kawasan ini terletak di antara sungai Sebangau dan sungai Katingan, dan berada di wilayah administrasi Kabupaten Katingan, Kabupaten Pulang Pisau dan Kota Palangkaraya,
Provinsi Kalimantan Tengah. Tujuan ditetapkannya Taman Nasional Sebangau (TNS) adalah untuk menyelamatkan ekosistem gambut beserta keanekaragaman hayati dan keunikan alam untuk kepentingan peningkatan kualitas hidup manusia generasi sekarang dan generasi yang akan datang (TNS, 2007).

Fungsi dan manfaat Taman Nasional Sebangau cukup strategis terhadap perbaikan kualitas lingkungan, sehingga keberadaannya menjadi perhatian dan tanggung jawab 
bersama pemerintah dan seluruh masyarakat. Masyarakat dapat memberikan saran, pertimbangan, pendapat, tanggapan untuk mewujudkan TNS sebagai salah satu kawasan konservasi yang berkelanjutan. Peran serta masyarakat tidak dapat dipisahkan dalam pengelolaan kawasan TNS agar nilai-nilai strategis tersebut dapat mengakomodasi kepentingan pemerintah maupun masyarakat. Kawasan TNS sebagai tempat konservasi berfungsi untuk melestarikan plasma nutfah yang sudah mencapai titik kritis.

Masyarakat lokal sekitarnya dapat menjadi ancaman tersediri bagi keberadaan kawasan TNS apabila masyarakat tidak mempunyai kepedulian terhadap kawasan. Fakta empirik menunjukkan bahwa pemanfaatan kayu non komersial di kawasan masih dilakukan masyarakat. Secara umum pola pemanfaatan kayu tersebut memiliki dimensi sosial yang berpengaruh terhadap eksistensi kawasan TNS.

Sebagian masyarakat sekitar melakukan pencurian kayu (illegal logging) di dalam kawasan. Beberapa tempat yang menjadi pintu gerbang atau akses masyarakat melakukan penebangan liar untuk masuk ke dalam kawasan, salah satunya adalah melewati Sungai Sebangau di Daerah Aliran Sungai (DAS) Sebangau. Salah satu faktor terjadinya penebangan liar di sekitar kawasan TNS karena aksesibilitas yang mudah. Apabila kondisi pemanfaatan yang tidak bertanggungjawab oleh masyarakat sekitar tidak dicegah, maka akan menjadi ancaman serius bagi keberadaan plasma nutfah kawasan TNS dan merupakan masalah yang perlu diatasi. Faktor lainnya yang mendorong terjadinya pencurian kayu secara illegal karena sebelumnya kawasan TNS adalah bekas Hak Pengusahaan Hutan HPH yang telah berakhir masa operasinya. Akibat tidak adanya pengelolaan kawasan $(\mathrm{HPH})$ sebelum ditetapkan sebagai TNS, kawasan ini menjadi tempat bagi penebang liar melakukan aksi, dan dikhawatirkan apabila tidak segera ditanggulangi akan merusak keberadaan ekosistem yang ada.

Kegiatan penebangan liar mengakibatkan berbagai perubahan lingkungan, antara lain perubahan bentang alam, perubahan habitat flora dan fauna, perubahan struktur tanah, perubahan pola aliran air permukaan dan air tanah dan sebagainya. Perubahan-perubahan tersebut menimbulkan dampak dengan intensitas dan sifat yang bervariasi. Selain perubahan pada lingkungan fisik, pertambangan juga mengakibatkan perubahan kehidupan sosial, budaya dan ekonomi.

Dalam menjalankan tugas pokok dan fungsinya, Taman Nasional Sebangau tidak hanya melakukan fungsi perlindungan dan pengamanan kawasan. Namun juga memperhatikan aspek lainnya, yaitu masyarakat di sekitar kawasan, khususnya kawasan perbatasan dengan desa penyangga kawasan. Desa Sebangau Mulya merupakan salah satu desa penyangga kawasan dan desa yang bersebelahan dan berjarak sekitar $9 \mathrm{~km}$ dari kawasan TNS. Masyarakat Desa Sebangau Mulya memiliki mata pencaharian bertani, berkebun karet dan ada yang menjadi tukang di luar Desa. Masyarakat Desa Sebangau Mulya umumnya pendatang dari Jawa, datangnya transmigrasi ini pada tahun 1988. Salah satu upaya TNS dalam memperhatikan masyarakat desa penyangga kawasan adalah melalui program pemberdayaan masyarakat. Program ini salah satu tujuannya adalah untuk mencegah masyarakat melakukan kegiatan yang dapat merusak ekosistem kawasan TNS dan sebagai salah satu bentuk keterlibatan masyarakat dalam pengelolaan kawasan TNS untuk kelestarian fungsi dan manfaat kawasan.

Pemberdayaan masyarakat adalah proses dimana masyarakat, khususnya mereka yang kurang memiliki akses kepada sumberdaya pembangunan didorong untuk meningkatkan kehidupan mereka. Pada prinsipnya adalah menempatkan masyarakat desa hutan sebagai pelaku utama dalam pengelolaan hutan secara partisipatif. Pemberdayaan masyarakat ini ditempuh melalui sosialisasi, pembentukan forum masyarakat dan kegiatan penyaluran bantuan. Pemberdayaan masyarakat di dalam dan sekitar hutan merupakan salah satu wujud pelaksanaan konstitusi negara. Pasal 33 UUD 1945 mengamanatkan agar penguasaan negara atas hutan ditujukan untuk sebesarbesar kemakmuran rakyat dan secara bersama-sama juga harus mengakomodir berbagai kelompok kepentingan baik, petani, peternak, peramu hasil hutan, masyarakat hukum adat maupun kepentingan lainnya. Salah satu program TNS dalam pemberdayaan masyarakat adalah melalui pemberian bantuan usaha ekonomi produktif.

Usaha ekonomi produktif dapat diartikan sebagai suatu aktivitas ekonomi yang dilakukan dengan penuh keyakinan dan secara terus menerus melalui berbagai cara untuk meningkatkan pemanfaatan nilai-nilai dari faktorfaktor produksi (sumber daya produktif) secara efektif dan efisien sehingga dapat menghasilkan barang dan/atau jasa yang dapat digunakan untuk mencukupi kebutuhan hidup. Salah satunya penyaluran bantuan dilakukan secara langsung oleh pihak TNS kepada kelompok masyarakat Desa Sebangau Mulya. Kegiatan ini berkesinambungan dan dikembangkan oleh masyarakat sendiri dalam wadah organisasi masyarakat setempat sendiri dalam wadah organisasi masyarakat setempat berdasarkan kebersamaan.

Program usaha ekonomi produktif telah berjalan selama lima tahun di Desa Sebangau Mulya. Namun keberhasilan program tersebut belum diketahui sehingga perlu evaluasi faktor-faktor yang mempengaruhi tingkat keberhasilan program usaha ekonomi produktif melalui analisis tingkat kesejahteraan masyarakat desa. Program usaha ekonomi produktif diharapkan akan mengakibatkan berbagai perubahan bagi masyarakat di sekitar kawasan TNS. Perubahan-perubahan tersebut menimbulkan dampak dengan intensitas dan sifat yang bervariasi. Dampak yang diharapkan secara positif dengan adanya program tersebut adalah bahwa masyarakat sekitar dapat menjaga ekosistem kawasan TNS sehingga lingkungan fisik yaitu kondisi flora dan fauna kawaan TNS dapat terjaga fungsi dan manfaatnya sebagai penyangga kehidupan, selain dampak yang ditimbulkan lainnya dari ekonomi dan sosial masyarakat diharapkan lebih sejahtera. 
Berdasarkan latar pemasalahan penelitian di atas maka perlu dilakukan penelitian tentang kajian evaluasi pengembangan usaha ekonomi produktif pada desa penyangga Sebangau Mulya di kawasan Taman Nasional Sebangau.

\section{METODOLOGI}

Tempat penelitian di Desa Sebangau Mulya, Kecamatan Sebangau Kuala, Kabupaten Pulang Pisau. Daerah penelitian ini ditentukan dengan metode purposive sampling dengan pertimbangan karena desa Sebangau Mulya merupakan salah satu desa percontohan konservasi yang berada di perbatasan dengan Kawasan Taman Nasional Sebangau dan telah menerima bantuan program usaha ekonomi produktif.

Pada penelitian ini yang dijadikan populasi adalah masyarakat Desa Sebangau Mulya yang menerima bantuan program UEP yang berjumlah 64 orang. Sampel dalam penelitian ini adalah $10 \%$ dari masyarakat Desa Sebangau Mulya yang menerima langsung bantuan program UEP yaitu sebanyak 40 orang sampel.

Penelitian ini dilakukan melalui 2 (dua) tahap analisis. Pertama, analisis data yang digunakan dalam penelitian kualitatif mencakup transkip hasil wawancara, reduksi data, analisis, interpretasi data dan triangulasi. Metode analisis deskriptif kualitatif selanjutnya dilakukan untuk mendeskripsikan pengembangan program usaha ekonomi produktif di desa Sebangau Mulya Kawasan Taman Nasional Sebangau. Kedua, menggunakan Analisis Regresi Linier Berganda dengan melakukan perhitungan skor dari setiap variabel dan total skor dari seluruh variabel menggunakan skala Likert. Analisis regresi linier berganda dapat diformulasikan ke dalam model matematis sebagai berikut (Simamora, 2004):

$$
\begin{aligned}
= & a+b 1 \times 1+b 2 \times 2+b 3 \times 3+b 4 X 4+b 5 \times 5+b 6 \times 6 \\
& +b 7 \times 7 \ldots \ldots+e
\end{aligned}
$$

\section{Keterangan:}

$$
\begin{array}{ll}
\mathrm{Y} & =\text { Tingkat kesejahteraan masyarakat } \\
\mathrm{X} 1 & =\text { Fasilitator } \\
\mathrm{X} 2 & =\text { Kelembagaan } \\
\mathrm{X} 3 & =\text { Kapasitas SDM } \\
\mathrm{X} 4 & =\text { Keterampilan dan Pengetahuan SDM } \\
\mathrm{X} 5 & =\text { Jenis Bantuan Ekonomi Produktif } \\
\mathrm{X} 6 & =\text { Penyuluhan dan Pelatihan } \\
\mathrm{X} 7 & =\text { Pengawasan } \\
\mathrm{a} & =\text { Bilangan konstanta } \\
\mathrm{b} 1, \mathrm{~b} 2 & =\text { Koefisien regresi } \\
\mathrm{e} & =\text { Residu }
\end{array}
$$

\section{HASIL}

\subsection{Pengembangan Program Usaha Ekonomi Produktif di Desa Sebangau Mulya Sekitar Kawasan Taman Nasional Sebangau}

Desa Sebangau Mulya Kawasan Taman Nasional Sebangau adalah salah satu desa konservasi yang mendapatkan program usaha ekonomi produktif dari Taman Nasional Sebangau. Desa ini bersinggungan dengan hutan konservasi Taman Nasional Sebangau dan letaknya paling ujung dari kawasan. Desa Konservasi Sebangau Mulya ditetapkan sebagai desa konservasi TN Sebangau melalui keputusan Kepala Balai Taman Nasional Sebangau Nomor SK.55/BTNS-1/Um/2013 tanggal 22 Agustus 2013.

Taman Nasional Sebangau sebelum memutuskan untuk memberikan bantuan program usaha, terlebih dahulu melakukan evaluasi. Kegiatan yang telah dilaksanakan dalam rangka evaluasi program usaha ekonomi produktif adalah identifikasi calon desa konservasi, sosialisasi program dan penguatan kelembagaan, peningkatan kapasitas kelembagaan dan penyusunan kesepakatan program dan pemberian bantuan pengembangan usaha, monitoring dan evaluasi.

Tahapan kegiatan dalam penentuan desa konservasi yang layak mendapatkan bantuan program usaha ekonomi kreatif adalah sebagai berikut:

1. Identifikasi calon desa konservasi

Taman Nasional sebangau dalam menentukan bantuan program ekonomi kreatif desa konservasi melibatkan peran serta berbagai pihak yaitu Pemerintah Daerah Pulang Pisau, Dinas Pertanian dan Perkebunan Pulang Pisau dan Bapai Penyuluhan Pertanian (BPP) Kecamatan Sebangau Kuala. Desa Sebangau Mulya layak mendapatkan bantuan program usaha ekonomi kreatif karena pada umumnya masyarakat desa Sebangau Mulya dalam memenuhi kebutuhan sehari hari hanya menggantungkan pemanfaatan sumberdaya alam di sekitar kawasan TN Sebangau. Aktivitas masyarakat sehari hari pada umumnya sebagai petani dan pekebun.

2. Sosialisasi program

Proses sosialisasi dilakukan oleh staf TN Sebangau dan para tokoh desa melalui rapat-rapat desa dengan memberikan pemahaman kepada masyarakat tentang pemberian bantuan program usaha ekonomi kreatif di lingkungan tempat tinggal mereka.

3. Penguatan kelembagaan

Penguatan kelembagaan perlu dilakukan melalui pembentukan kelembagaan pada tingkat desa dan melalui kerjasama atau kemitraan. Dalam hal kemitraan maka TN Sebangau melibatkan Balai Penyuluh Pertanian (BPP) Kecamatan Sebangau Mulya untuk membantu. aktivitas manajemen sumberdaya manusia masyarakat. Penguatan kelembagaan pada tingkat Desa Sebangau Mulya diharapkan dapat terbentuk melalui pembentukan kelembagaan masyarakat di tingkat desa. 
4. Peningkatan kapasitas kelembagaan

Kelembagaan dalam konteks pengembangan program bantuan ekonomi kreatif lebih ditujukan kepada kelembagaan baru di tingkat desa yang berperan aktif dalam mendukung keberhasilan program. Fungsi utama dari kelembagaan tersebut sebagai wadah dan organisasi pengembangan sumberdaya manusia, dalam hal ini masyarakat desa Sebagau Mulya. Peningkatan kapasitas kelembagaan dilakukan melalui aktivitas organisasi yang dilakukan secara kontinyu dalam pengembangan program usaha.

5. Penyusunan kesepakatan program

Berdasarkan hasil rapat yang dilakukan oleh pihak TN Sebangau, BPP Kecamatan Sebagau Kuala, tokoh masyarakat dan masyarakat Desa Sebangau Mulya maka ditentukan program bantuan yang diberikan. Hasil kesepakatan melalui diskusi tersebut menjadi dasar dalam penetepan jenis program yang disesuaikan dengan kondisi desa Sebangau Mulya dan masyarakat sebagai pelaku penerima bantuan. Dua jenis program yang ditetapkan pada tahun 2013 adalah pemberian bantuan hewan ternak dan bantuan bibit karet.

6. Pemberian bantuan pengembangan usaha

Pengembangan program usaha ekonomi produktif di desa Sebangau Mulya dimulai pada tahun 2013, dengan pertama kali pemberian bantuan berupa hewan ternak dan bibit karet entres. Program usaha ekonomi produktif di Desa Sebangau Mulya disajikan pada Tabel 1 dan sebagian realisasinya disajikan pada Gambar 1.

7. Monitoring dan Evaluasi

Pemberian bantuan program usaha ekonomi produktif di Desa Sebangau Mulya perlu dilakukan monitoring dan evaluasi. Kegiatan evaluasi bantuan dilaksanakan hanya sebatas pada kelompok masyarakat penerima bantuan. Kegiatan evaluasi dilakukan mengacu pada pada pedoman monitoring dan evaluasi pemberdayaan masyarakat di sekitar kawasan konservasi, Direktorat Jenderal PHKA tahun 2008.

Hasil monitoring dan evaluasi menunjukkan bahwa dalam pengembangan program usaha ekonomi produktif telah terbentuk kelembagaan pada tingkat masyarakat yaitu Gabungan Kelompok Tani (Gapoktan) Desa Sebangau Mulya. Pada saat kegiatan monitoring, kelembagaan masyarakat terutama kelompok bantuan sapi berfungsi dengan baik dan Gapoktan sangat aktif terlibat dalam memantau keberhasilan bantuan dari Balai TN Sebangau. Selain itu fasilitator yang melibatkan penyuluh pertanian dari Balai Penyuluh Pertanian (BPP) Kecamatan Sebangau Kuala efektif melakukan pendampingan.

Tabel 1. Pengembangan program usaha ekonomi produktif di Desa Sebangau Mulya

\begin{tabular}{|c|c|c|c|c|}
\hline No. & Bantuan Program & $\begin{array}{l}\text { Jumlah Awal Ban- } \\
\text { tuan }\end{array}$ & $\begin{array}{l}\text { Jumlah Akhir } \\
\text { Pengembangan } \\
\text { Bantuan }\end{array}$ & Keterangan \\
\hline 1 & Hewan ternak sapi & 6 ekor sapi (2013) & 18 ekor sapi (2018) & $\begin{array}{l}\text { Terdapat pengembangan } 12 \text { hewan ter- } \\
\text { nak sapi dari pemberian } 6 \text { ekor sapi men- } \\
\text { jadi } 18 \text { ekor sapi }\end{array}$ \\
\hline 2 & Bibit karet & 2000 bibit (2013) & 0 bibit (2018) & $\begin{array}{l}\text { Terbakar akibar kebakaran hutan pada } \\
\text { tahun } 2015\end{array}$ \\
\hline 3 & Hewan ternak kambing & $\begin{array}{l}13 \text { ekor kambing } \\
\text { (2017) }\end{array}$ & $\begin{array}{l}40 \text { ekor kambing } \\
\text { (2018) }\end{array}$ & $\begin{array}{l}\text { Terdapat pengembangan } 27 \text { ekor kamb- } \\
\text { ing sejak pemberian bantuan } 13 \text { ekor } \\
\text { kambing pada tahun } 2017\end{array}$ \\
\hline
\end{tabular}
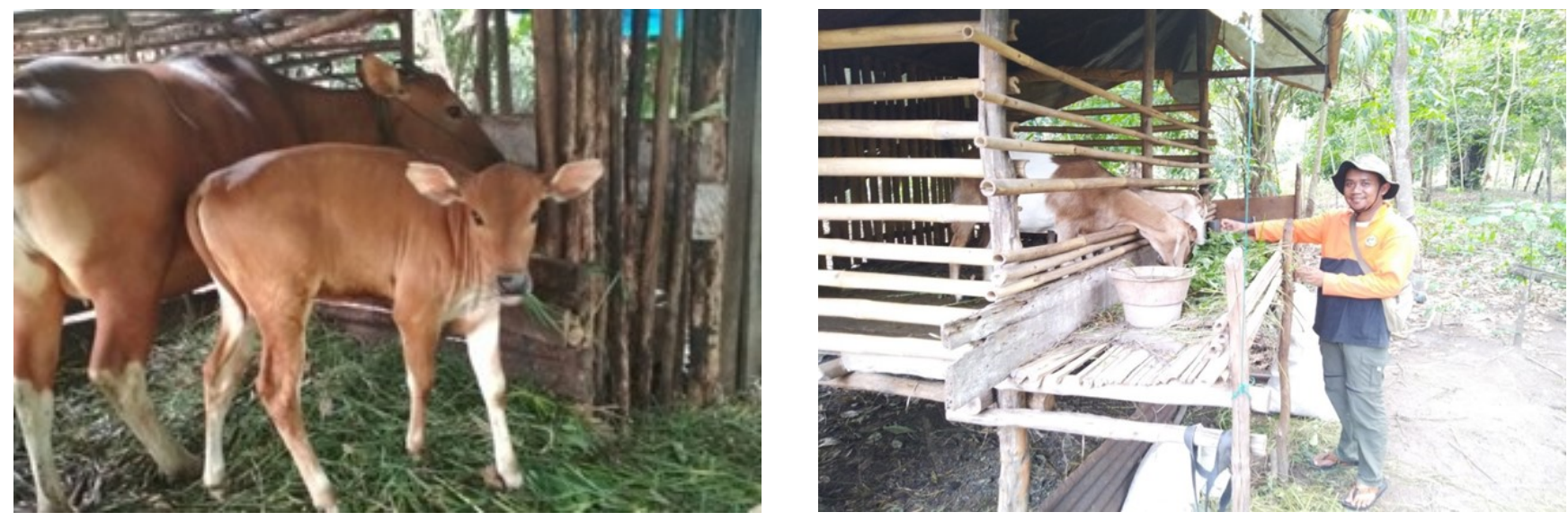

Gambar 1. Ternak sapi dan kambing hasil program usaha ekonomi produktif kelompok Tani Wana Mulya Desa Sebangau Mulya 


\subsection{Faktor-faktor Program Usaha Ekonomi Produktif Yang Mempengaruhi Tingkat Kesejahteraan Masyarakat Desa Sebangau Mulya Sekitar Kawasan Taman Nasional Sebangau}

Penelitian pada tahap ini bertujuan untuk mengetahui faktor-faktor program usaha ekonomi produktif yang mempengaruhi tingkat kesejahteraan masyarakat Desa Sebangau Mulya dengan menggunakan variabel bebas dan variabel terikat. Analisis untuk mengetahui faktor-faktor yang mempengaruhi variabel $\mathrm{X}$ terhadap Variabel $\mathrm{Y}$ adalah menggunakan uji $F$ melalui software SPSS versi 2.0. Uji $F$ dalam analisis regresi linear berganda bertujuan untuk mengetahui apakah variabel bebas $(X)$ secara bersamasama atau secara serempak (simultan) berpengaruh terhadap variabel terikat $(\mathrm{Y})$.

Berdasarkan teori bahwa jika nilai $F_{\text {hitung }}>F_{\text {tabel }}$ maka variabel bebas $(X)$ berpengaruh terhadap variabel terikat (Y) dan Jika Sig. < 0,05 maka variabel bebas $(X)$ berpengaruh signifikan terhadap variabel terikat $(Y)$ (Sujarweni, 2015). Hasil penelitian menunjukkan bahwa variabel bebas Fasilitator (X1), Kelembagaan (X2), Kapasitas SDM (X3), Keterampilan dan Pengetahuan SDM (X4), Jenis Bantuan Ekonomi Produktif (X5), Penyuluhan dan Pelatihan (X6), dan Pengawasan (X7), tidak memberikan pengaruh yang signifikan secara simultan terhadap tingkat kesejahteraan masyarakat. Hasil ini dapat dilihat dari hasil uji $F_{\text {hitung }}=1,672>F_{\text {tabel }} 2330$ dan nilai sig $>0,05$ yaitu sig $=0,152$.

Besarnya harga koefisien determinasi juga dapat digunakan untuk menjelaskan sumbangan pengaruh variabel bebas $(\mathrm{X})$ secara simultan terhadap variabel terikat (Y). Besarnya harga koefisien determinasi adalah berkisar 0 $<\mathrm{R} 2<1$. Artinya jika R square mendekati 1 maka dapat dikatakan pengaruh variabel bebas terhadap variabel terikat adalah besar. Berarti model yang digunakan baik untuk menjelaskan pengaruh variabel tersebut. Nilai $R$ square hasil penelitian yaitu 0,268 dan $R$ sebesar 0,517 yang berarti bahwa faktor faktor variabel bebas secara simultan dalam mempengaruhi tingkat kesejahteraan masyarakat sebesar $26,80 \%$ dan sisanya dipengaruhi oleh faktor lainnya.

Penentuan model regresi linier berganda dapat menjelaskan pengaruh variabel bebas terhadap variabel terikat. Penentuan model regresi linier berganda dapat dilihat berdasarkan hasil uji t. Nilai t hitung dibandingkan dengan $\mathrm{t}$ tabel dengan tingkat kepercayaan 95\% atau $\alpha=$ $5 \%$ dengan ketentuan jika $t_{\text {tabel }}<t_{\text {hitung }}<t_{\text {tabel, }}$ maka variabel bebas tersebut dikeluarkan dari model regresi linier berganda. Jika $t_{\text {hitung }}=t_{\text {tabel }}$ atau $t_{\text {hitung }}=-t_{\text {tabel, }}$ maka variabel bebas tersebut tidak dikeluarkan dari model regresi linier berganda. Uji t digunakan untuk mengetahui apakah variabel bebas secara parsial atau sendiri sendiri berpengaruh terhadap variabel terikat. Berdasarkan nilai signifikansi, jika nilai sig < 0,05, maka ada pengaruh variabel bebas $(X)$ secara parsial terhadap variabel terikat $(Y)$. Berdasarkan nilai $t_{\text {hitung, }}$ jika nilai $t_{\text {hitung }}>t_{\text {tabel }}$ maka ada pengaruh variabel bebas secara partial terhadap variabel terikat $(\mathrm{Y})$.

Nilai t tabel yaitu 2,040. Berdasarkan hal tersebut maka variabel bebas yang mempunyai pengaruh signifikan terhadap peningkatan kesejahteraan masyarakat adalah variable X4 yaitu keterampilan dan pengetahuan dengan $t_{\text {hitung }}(2,237)>t_{\text {tabel }}(2,040)$. Berdasasrkan hasil analisis uji Model regresi linier untuk persamaan faktor-faktor program usaha ekonomi produktif yang mempengaruhi tingkat kesejahteraan masyarakat Desa Sebangau Mulya adalah sebagai berikut:

\section{$Y=-3,096+0,362 X 1+0,559 X 2-0,138 X 3+0,989 X 4+$ $0,120 \times 5-0,794 \times 6+0,992 \times 7$}

Sementara itu pengaruh faktor $X$ secara parsial dapat dihitung melalui rumus Sumbangan Efektif. Sumbangan Efektif (SE) keterampilan dan pengetahuan (X4) dalam mempengaruhi tingkat kesejahteraan masyarakat Desa Sebangau Mulya dapat dihitung dengan rumus:

$$
\operatorname{SE}(X) \%=\text { Beta }_{x} \times r_{x y} \times 100 \%
$$

Dari rumus tersebut diperoleh bahwa SE (X4) sebesar $26,80 \%$. Itu berarti bahwa besarnya kontribusi faktor keterampilan dan pengeahuan bersifat dominan terhadap tingkat kesejahteraan masyarakat Desa Sebangau Mulya yaitu sebesar $26,80 \%$.

\section{PEMBAHASAN}

\subsection{Pengembangan Program Usaha Ekonomi Produktif di Desa Sebangau Mulya Sekitar Kawasan Taman Nasional Sebangau}

Responden dalam penelitian ini adalah masyarakat yang menerima bantuan program usaha ekonomi produktif di Desa Sebangau Mulya. Pada umumnya responden mempunyai pekerjaan petani (67,50\%) dan pekebun (30,00\%). Responden petani selama ini melakukan aktivitas bertani dengan menanam padi tadah hujan selama satu tahun sekali. Responden yang melakukan aktivitas berkebun dengan menanam karet, sengon dan singkong. Hasil pertanian dan perkebunan selama ini hanya cukup untuk menghidupi kebutuhan hidup sehari hari keluarga, sehingga responden layak mendapatkan bantuan program usaha ekonomi produktif.

Berdasarkan hasil monitoring dan evaluasi dari program usaha ekonomi yang diberikan di Desa Sebangau Mulya maka dapat diketahui beberapa hal sebagai berikut yaitu:

1. Indikator terbangunnya kesepahaman dengan para pihak terkait dengan kegiatan pemberdayaan masyarakat di Desa Sebangau Mulya. Kesepahaman para pihak dapat dilihat dari beberapa hal antara lain partisipasi Pemerintah Daerah Pulang Pisau yang 
mendukung program desa konservasi Sebangau Mulya, Dinas Pertanian dan Perkebunan Pulang Pisau yang memfasilitasi kawin suntik bagi bibit sapi yang siap kawin, peyuluhan rutin perbulan yang dilakukan oleh Balai Penyuluhan Pertanian (BPP) Kecamatan Sebangau Kuala (ternak dan kebun).

2. Telah terdapat fasilitator/pendamping kegiatan pemberdayaan masyarakat di lapangan yang efektif. Fasilitator atau pendamping yang ditugaskan secara khusus dari Balai TN Sebangau. Balai TN Sebangau saat ini baru melakukan komunikasi efektif dengan BPP Kecamatan Sebangau Kuala untuk bersama-sama melakukan pendampingan di desa tersebut.

3. Terbangun dan berkembangnya kelembagaan masyarakat di tingkat desa, dan berfungsi dengan baik. Pada saat kegiatan monitoring, kelembagaan masyarakat terutama kelompok bantuan sapi dari Balai TN Sebangau berfungsi dengan baik. Untuk kelembagaan mayarakat tingkat desa dan Gapoktan sangat aktif terlibat dalam memantau keberhasilan bantuan dari Balai TN Sebangau.

4. Kapasitas SDM (pengelola dan masyarakat) meningkat. Kapasitas SDM pengelola kelompok peternakan sapi Wana Mulya dan masyarakat dapat dikategorikan meningkat, hal ini seiring dengan aktivitas penyuluhan oleh BPP Kecamatan Sebangau Kuala dan kegiatan peningkatan kapasitas oleh Balai TN Sebangau.

5. Ketrampilan dan pengetahuan SDM (pengelola dan masyarakat) meningkat. Tim pelaksana kegiatan monitoring menyimpulkan bahwa tingkat ketrampilan dan pengetahuan masyarakat meningkat salah satunya karena kegiatan pelatihan yang diselenggarakan oleh Balai TN Sebangau.

6. Kegiatan usaha ekonomi masyarakat telah berkembang. Secara keseluruhan dengan bantuan sapi 6 ekor dan bibit karet entres 2.000 bibit belum dapat digunakan untuk mengukur apakah telah mendukung penuh usaha ekonomi masyarakat atau belum. Namun demikian, dengan adanya bantuan sapi dari Balai TN Sebangau diharapkan dapat meningkatkan usaha ekonomi di Desa Sebangau Mulya.

7. Terbangunnya jejaring kerja dengan pola kemitraan. Hasil panen usaha pertanian (padi, palawija, hortikultura) di Sebangau Mulya masih digunakan untuk memenuhi kebutuhan hidup sehari-hari masyarakat. Usaha perkebunan karet menurut beberapa warga rata-rata belum memasuki usia panen, jikalau ada hanya sedikit sehingga belum dilakukan kerjasama dengan pihak-pihak tertentu untuk membangun kemitraan. Penjualan karet biasanya dibawa ke Pulang Pisau. Sedangkan usaha peternakan sapi masih dipasarkan di lingkup Kecamatan Sebangau Kuala. Berdasarkan hasil wawancara tersebut, maka disimpulkan bahwa di Desa Sebangau Mulya belum terbangun jejaring kerja dengan pola kemitraan.

8. Terpeliharanya fungsi kawasan. Kawasan TN Sebangau di wilayah administrasi Kabupaten Pulang Pisau sudah dilakukan tata batas definitif dengan jarak dari Desa Sebangau Mulya kurang lebih berjarak $9 \mathrm{~km}$ sehingga sampai dengan saat ini masih terpelihara dengan baik.

9. Terbentuk dan berfungsinya MPA. Masyarakat Peduli Api (MPA) di Desa Sebangau Mulya berfungsi sangat optimal. Setiap tahun, MPA di Desa Sebangau Mulya mendapat alokasi dana dari Pemerintah Desa dengan jumlah anggaran antara 3 s.d 5 juta per tahun. Dengan kondisi ini maka MPA Desa Sebangau Mulya telah berfungsi dengan baik.

Pengembangan program usaha ekonomi produktif di Desa Sebangau Mulya tidak terlepas dari adanya hambatan dalam menjalankan program. Hambatan yang dapat diidentifikasi adalah adanya kebakaran hutan dan lahan (karhutla) pada tahun 2015 yang berdampak pada tanaman bibit karet terbakar. Sejumlah titik api kembali muncul akibat tiupan angin kencang dan cuaca panas di lahan tumbuhnya bibit karet, sehingga bantuan bibit karet sejumlah 2000 bibit yang diberikan ke masyarakat secara keseluruhan mengalami kematian. Dampak kebakaran hutan dan lahan juga menyebabkan asap karhutla yang menyerang kawasan peternakan masyarakat mempengaruhi kondisi ternak sapi. Sumber pakan ternak yang berupa tumbuhan lokal berkurang akibat terbakarnya semak dan tumbuhan yang digunakan hijauan pakan mengalami kebakaran. Faktor penting dalam kegiatan beternak yaitu ternak sapi yang nyata adalah suplai asupan pakan yang konsisten dalam pemberian pakan baik secara kualitas dan kuantitas. Kejadian karhutla menyebabkan kestersediaan pakan hijauan ternak mengalami kekurangan.

Program usaha ekonomi kreatif di Desa Sebangau Mulya yang diberikan TN Sebangau menunjukkan manfaat yang positif. Kriteria penerimaan manfaat yang positif dapat dilihat dari enam indikator yang menguatkan tersebut adalah indikator terbangunnya kesepahaman dengan para pihak terkait dengan kegiatan pemberdayaan masyarakat, terbangun dan berkembangnya kelembagaan masyarakat di tingkat desa, dan berfungsi dengan baik, kapasitas SDM (pengelola dan masyarakat) meningkat, ketrampilan dan pengetahuan SDM (pengelola dan masyarakat) meningkat, terpeliharanya fungsi kawasan, terbentuk dan berfungsinya kelompok MPA di Desa Sebangau Mulya. Harapan dari keberlanjutan program usaha ekonomi kreatif adalah bahwa masyarakat di Desa Sebangau Mulya mempunyai komitmen terhadap pengelolaan kawasan TN Sebangau dengan ditunjukkannya kepedulian masyarakat terhadap kelestarian kawasan konservasi.

Manfaat yang dirasakan baik TN Sebangau sebagai salah satu unsur pemerintah maupun masyarakat adalah program ini dapat menjembatani relasi antara pemerintah dan masyarakat dalam pembangunan desa. Adanya partisipasi masyarakat secara langsung dalam semua proses mulai dari tahap merencanakan, membuat, dan mengimplementasikan program yang dilaksanakan di Desa 
Sebangau Mulya dapat mendukung keberhasilan program. Sururi (2015) menjelaskan bahwa dalam program pemberdayaan masyarakat akan dapat menumbuhkan partisipasi masyarakat yang dapat disebabkan oleh adanya kesempatan yang diberikan kepada masyarakat untuk berpartisipasi, adanya kemauan masyarakat dan adanya kemampuan masyarakat untuk berpartisipasi. Partisipasi masyarakat di Desa Sebangau Mulya juga dapat dilihat dari keaktifan masyarakat dalam menghadiri setiap musyarah desa dengan TN Nasional Sebangau serta kegiatan penyuluhan dan pelatihan yang diprogramkan oleh TN Sebangau.

Program usaha ekonomi kreatif yang diberikan TN Sebangau untuk masyarakat di Desa Sebangau Mulya diharapkan dapat membangkitkan kembali semangat gotong royong di kalangan masyarakat yang mulai pudar serta dapat menurunkan tingkat dependensi masyarakat terhadap sumber daya alam Kawasan TN Sebangau. Sumber daya alam yang terdapat di Kawasan Taman Nasional Sebangau termasuk keanekaragaman hayati yang terkandung di dalamnya perlu dikelola secara lestari dan berkelanjutan. Masyarakat di sekitar hutan konservasi TN Sebangau tidak hanya ditekankan untuk tidak merambah dan menggunakan kawasan Taman Nasional tetapi masyarakat juga memiliki peran untuk menjaga kelestarian ekosistem Taman Nasional.

\subsection{Faktor-faktor Program Usaha Ekonomi Produktif Yang Mempengaruhi Tingkat Kesejahteraan Masyarakat Desa Sebangau Mulya Sekitar Kawasan Taman Nasional Sebangau}

Hasil analisis regresi menunjukkan bahwa peningkatan kesejahteraan masyarakat sangat dipengaruhi oleh variabel keterampilan dan pengetahuan (X4). Upaya dalam peningkatan kesejahteraan, masyarakat memetakan hambatan dan menemukan solusi dalam diskusi yang dilakukan kelompok tani untuk pengembangan usaha ekonomi yang mereka lakukan. Melalui keterampilan dan pengetahuan yang diperoleh selama ini, masyarakat melakukan improvisasi pengembangan usaha. Menurut Samsiyah dan Rudyanto (2015), keterampilan adalah kemampuan untuk menggunakan akal, pikiran, ide dan kreatifitas dalam mengerjakan, mengubah maupun untuk membuat sesuatu yang lebih bermakna sehingga menghasilkan sebuah nilai dari hasil pekerjaan tersebut. Keterampilan dipengaruhi oleh tiga fakor yaitu, motivasi, pengalaman, dan keahlian. Menurut Notoatmodjo (2012), pengetahuan adalah hasil dari tahu dan ini terjadi setelah seseorang melakukan penginderaan terhadap suatu objek. Penginderaan terjadi melalui pancaindera manusia yakni, indera pendengaran, penglihatan, penciuman, perasaan dan perabaan. Faktor yang mempengaruhi pengetahuan adalah pendidikan, umur, dan pengalaman.

Tingkat pendidikan responden pada penelitian ini adalah SD (40,00\%), SLTP (42,50\%), dan SLTA (47,50\%). Pengetahuan yang diperoleh responden selain dari pendidikan formal juga diperoleh dari pendidikan non formal. Berkaitan dengan penelitian ini, maka pendidikan non formal yang diperoleh melalui penyuluhan dan pelatihan yang diberikan oleh fasilitator TN Sebangau. Walaupun variabel penyuluhan dan pelatihan (X6) tidak mempunyai pengaruh baik secara partial dan simultan bersama sama dengan variabel bebas lainnya dalam analisis regresi, namun penyuluhan dan pengetahuan berkontribusi langsung terhadap pengetahuan masyarakat dalam menjalankan program. Keterampilan dan pengetahuan yang dimiliki masyarakat Desa Sebangau Mulya digunakan dalam rangka pengembangan usaha ekonomi kreatif lainnya.

Pada penelitian ini jenis bantuan ekonomi produktif tidak berpengaruh terhadap tingkat kesejahteraan masyarakat. Hal ini diduga, masyarakat selain menjalankan program usaha ekonomi produktif dari TN Sebangau, sebagian masyarakat juga melakukan jenis usaha lainnya dalam mencukupi ekonomi keluarga. Salah satu contohnya adalah masyarakat di Desa Sebangau Mulya yang tergabung dalam kelompok Tani Wana Mulya mengembangkan keyakinan untuk berusaha memenuhi kebutuhan sesuai dengan skala prioritas berdasarkan atas sumber yang ada dalam masyarakat sendiri maupun dari luar dengan usaha secara gotong royong. Upaya pengembangan tersebut adalah melalui produksi sarang wallet yang hasilnya dapat bermanfaat meningkatkan kesejahteraan. Pengembangan usaha lainnya yang dilakukan masyarakat oleh Kelompok Tani Wana Mulya khususnya usaha sarang burung wallet dapat memberikan nilai tambah secara ekonomi. Nilai ekonomi usaha burung wallet yang dilakukan pada tahun 2013 telah dapat memberikan panen sarang burung wallet pada tahun 2015 dengan panen dalam setahun 6 kali. Kisaran nilai ekonomi dalam setiap produksi sarang burung walet Rp. 170.000 .000 dalam 11 bulan.

Program yang diberikan TN Sebangau maupun usaha pengembangan lainnya sarang burung wallet dapat meminimalkan ketergantungan masyarakat terhadap sumber daya alam di kawasan TN Sebangau. Program yang telah diimplementasikan TN Nasional Sebangau dalam memberdayakan masyarakat tentu membutuhkan proses yang tidak cepat dan mudah, khususnya aspek perubahan cara pandang (mindset) masyarakat agar dapat berbenah diri mengurangi ketergantungan sumber daya alam dan untuk kemudian memberikan dampak perubahan bagi mereka.

Program usaha ekonomi produktif yang telah dilakukan TN Sebangau merupakan salah satu bentuk memberdayakan masyarakat melalui pemberian bantuan ternak pada salah satu desa konservasi, yaitu desa Sebangau Mulya. Program ini ditinjau dari hasil telah memberikan manfaat positif bagi pengetahuan dan keterampilan masyarakat dalam mengoptimalkan hasil. Program pemberdayaan masyarakat dalam bentuk bantuan ternak, juga dilakukan oleh TN Gunung Halimun Salak. Penelitian Sahab et al. (2015) menunjukkan bahwa 
diperolehnya strategi pemberdayaan masyarakat dalam pengelolaan TNGHS kolaboratif yang mengintegrasikan antara pengelolaan taman nasional bersama masyarakat dengan pengembangan usaha ternak masyarakat secara bersama dan professional.

Pemberdayaan masyarakat pada dasarnya upaya membangkitkan potensi yang ada dalam diri individu atau kelompok dengan memberikan dorongan, memberikan kesadaran akan potensi yang dimiliki orang atau kelompok tersebut dengan tujuan pemberdayaan mengarah kepada keadaan capaian atau yang ingin dihasilkan kearah perubahan masyarakat yang berdaya guna dan memiliki kemampuan dalam merubah dan memperbaiki kehidupan sosial ekonomi masyarakatnya. Potensi yang dapat digali dari individu atau kelompok dapat berasal dari potensi lokal dan potensi sumber daya alam. Potensi lokal berupa sumber daya manusia sebagai subyek pembangunan mengetahui permasalahan masyarakat sendiri sedangkan sumber daya alam merupakan kekayaan yang dimanfaatkan untuk mengangkat kesejahteraan sosial ekonomi masyarakat desa (Endah, 2020).

\section{KESIMPULAN}

Kesimpulan penelitian ini adalah sebagai berikut:

1. Pengembangan program usaha ekonomi produktif di Desa Sebangau Mulya Kawasan Taman Nasional Sebangau memberikan manfaat positif dengan dihasilkannya penambahan jumlah produksi ternak sapi dan kambing dari TN Sebangau. Terdapat pengembangan 12 hewan ternak sapi dari pemberian 6 ekor sapi menjadi 18 ekor sapi dan terdapat pengembangan 27 ekor kambing sejak pemberian bantuan 13 ekor kambing.

2. Faktor-faktor program usaha ekonomi produktif yang berpengaruh secara partial terhadap tingkat kesejahteraan masyarakat Desa Sebangau Mulya kawasan Taman Nasional Sebangau adalah keterampilan dan pengetahuan, sedangkan faktor lainnya tidak berpengaruh signifikan terhadap tingkat kesejahteraan masyarakat.

\section{DAFTAR PUSTAKA}

Endah, K., 2020. Pemberdayaan Masyarakat: Menggali Potensi Lokal Desa. Moderat: Jurnal Ilmiah Ilmu Pemerintahan, 6(1), 135-143.

Notoatmodjo. S., 2012. Promosi Kesehatan dan Perilaku Kesehatan. Jakarta: PT Rineka Cipta

Sahab, A., Darusman, D. and Muladno, M., 2015. Penguatan Pengelolaan Taman Nasional Gunung Halimun Salak Melalui Pemberdayaan Masyarakat Berbasis Pengembangan Peternakan Ruminansia. Risalah Kebijakan Pertanian dan Lingkungan: Rumusan Kajian Strategis Bidang Pertanian dan Lingkungan, 2 (2), 87-97.

Samsiyah, N. and Rudyanto, H. E., 2015. Kemampuan Berpikir Kreatif Dalam Memecahkan Masalah Matetatika Open-Ended Ditinjau Dari Tingkat Kemampuan Matematika Siswa Sekolah Dasar. Pedagogia: Jurnal Pendidikan, 4(1), 23-33.

Simamora, H., 2004. Manajemen Sumber Daya Manusia. Yogyakarta: STIE YKPN.

Sujarweni, V. W., 2015. Akuntansi Biaya. Yogyakarta: Pustaka Baru Press.

Sururi, A. (2015). Pemberdayaan masyarakat melalui program pembangunan infrastruktur perdesaan dalam meningkatkan kesejahteraan masyarakat Kecamatan Wanasalam Kabupaten Lebak. Sawala: Jurnal Administrasi Negara, 3(2), 1-25.

Taman Nasional Sebangau. 2007. Rencana Pengelolaan Taman Nasional Sebangau Priode 2007-2026 Provinsi Kalimantan Tengah. 155 p. 